\title{
Infância e errância: imagens da criança abandonada na ficção brasileira
} Licia Soares de Souza ${ }^{1}$

A infância, tantas vezes presente na literatura brasileira, em representações edênicas, é tomada, por outro lado, como uma época sofrível, um tempo socialmente perdido durante o qual crianças abandonadas à própria sorte vivem em meios perigosos, aprendendo o ofício do crime. Geralmente, são construídas configurações sociais que indicam experiências de ruptura, em que algumas crianças perdem os elos familiares, ganham as ruas, são resgatadas por instituições desumanizadas que oprimem mais do que educam, ou por organizações criminosas ligadas ao tráfico contemporâneo de drogas. A infância funciona então como força semântica e fonte de experiência discursiva, permitindo ao escritor denunciar a falência de uma ordem sociopolítica inapta a cuidar de cidadãos carentes.

Em 1937, Jorge Amado compôs uma trama de meninos de rua, conhecidos, na época, como "capitães da areia", que teriam a rua como educadora, desafiando todos os representantes do poder local, a polícia, o clero conservador e a burguesia nascente nos belos casarões ajardinados do Corredor da Vitória, símbolo de riqueza na cidade de Salvador. Nessa década, o Brasil ainda não possuía um tráfico de drogas organizado (que será sistematizado durante a ditadura militar de 1964 a 1985), e o modo de existência dos pequenos infratores aparecia como consequência de um modelo de desenvolvimento excludente que já ia produzindo desigualdades sociais e miséria. Percorrendo as ruas da cidade e o caminho do mar, os capitães da areia enfrentavam o poder local, em suas atividades ilícitas, mas desenvolviam sua própria metodologia de formação baseada em códigos de solidariedade e ajuda mútua com os quais eles se protegiam contra a ordem constituída da qual brotavam certas práticas severamente punitivas.

Após o golpe militar de 1964, que aumentou o declive entre as classes, a ficção brasileira foi desenvolvendo uma espécie de realismo feroz (Candido, 1989), como se a literatura tomasse para si a

\footnotetext{
${ }^{1}$ Doutora em semiologia e professora titular da Universidade do Estado da Bahia (UNEB), Salvador, BA, Brasil. E-mail: liciasos@ hotmail.com
} 
principal responsabilidade de espelhar a desagregação social agravada por um regime militar autoritário. Rubem Fonseca, nos anos 1980, mostrou crianças marginais sem os sentimentos de solidariedade de grupo, sem o respeito pelos objetos sagrados da tradição afro-brasileira (eles chutam os presentes de Iemanjá nas praias), mas já deixando entrever "o brutalismo social que vinha se acentuando com a política de concentração de renda e de exclusão das minorias pobres e negras" (Bispo, 2009, p. 304). ${ }^{2}$

No fim do século $X X$, os escritores e cineastas aproveitaram o embrião narrativo de Rubem Fonseca, que já entrevia a perspectiva conflitante que a violência real projetaria na moderna arte nacional, para dar conta de uma representação de grupos de bandidos sociais, geralmente negros, que ultrapassariam as formações ideológicas da malandragem, para expressarem suas revoltas diante das classes mais abastadas, com armas sofisticadas nas mãos. Foi a época da produção ficcional de autores advindos da periferia das cidades, cujas vozes inaugurariam dispositivos de enunciação diretamente relacionados a seus mundos empíricos, dando origem a um discurso literário específico. Exemplos marcantes são o de Paulo Lins, com Cidade de Deus (1997), e Reginaldo Ferreira da Silva, de nome literário Ferréz, com Manual prático do ódio (2003), que começaram a produzir matéria romanesca gerada de suas vivências nesse espaço de exclusão radical. Pois bem, a identidade das forças temáticas privilegiadas por Lins e Ferréz, ancorada na formação de quadrilhas bastante hierarquizadas com os códigos de funcionamento do tráfico de drogas, implica uma visão de mundo que passa da dialética da malandragem ${ }^{3}$ a uma dialética da marginalidade. ${ }^{4}$ É uma passagem

\footnotetext{
${ }^{2}$ Em novembro de 1939, 8.080 exemplares de Capitães da areia foram queimados em praça pública, sob o pretexto de se tratar de objeto de propaganda comunista. No dia 8 de dezembro do mesmo ano, a obra foi apreendida nas livrarias do Rio de Janeiro, sob a alegação de ser nefasta à sociedade. E o livro de contos Feliz Ano Novo, de Rubem Fonseca, nos anos 1980, foi proibido pelo regime militar.

${ }^{3}$ A dialética da malandragem foi pensada por Antonio Candido (1993), na qual o malandro, como representação de um sujeito nacional, utiliza mecanismos de esperteza para sobreviver numa sociedade de exclusão, sem causar danos mortais a essa sociedade. Assim sendo, ele é um personagem simpático, e suas ações são aceitáveis pelo imaginário da sociedade nacional.

${ }^{4}$ A dialética da marginalidade é um conceito desenvolvido por João César Rocha (2004). A nova estética não se pauta mais sobre a conciliação, pois a violência se sobrepõe à esperteza, no combate de uma sociedade injusta. Dialeticamente, as obras contempladas pelo ângulo da marginalidade mostram que tanto a sociedade como o crime têm faces perversas. E a perversa realidade que
} 
que possui seu interesse literário na medida em que instaura um projeto identitário, transmitindo um objetivo político de combate aos ideais das classes abastadas, exibindo uma linguagem própria praticada por sujeitos pertencentes à periferia, aprisionados pelas atividades ilícitas da marginalidade.

A produção marginal adota efetivamente as perspectivas do realismo brutalista, utilizando uma série de procedimentos que Alfredo Bosi (2002) classifica como hipermimetismo. Muito já se falou que uma chamada literatura marginal parecia fortalecer as articulações entre a ficção e a realidade. Ela revigorava os princípios criativos do realismo-naturalismo em suas formas de dirigir o olhar para as condições físicas das periferias urbanas, em uma época de descentramento entre a representação e seus objetos referenciais. Mas alguns estudiosos da literatura brasileira contemporânea foram destacando a consolidação de uma literatura de periferia, importante não apenas para o mercado editorial, como igualmente para a indústria cultural de filmes e documentários. Lembremo-nos de Beatriz Jaguaribe (2010), que observa que as novas estéticas realistas não repetem necessariamente os cânones do passado, e sim delineiam uma prosa ágil na qual o mundo dos personagens é dinamizado pela ação e pelas falas, em detrimento de longas descrições do ambiente, e essas falas pluralizadas enfraquecem igualmente a autoridade do narrador realista onisciente. Nesse contexto, conclui a autora, o realismo, que rege esse tipo de literatura de periferia, não pode ser caracterizado de forma simplista como signo de atraso estético, ${ }^{5}$ mas sim como uma postura e um método, cada vez mais em uso, aptos a revelar a função e o valor de boa parte da produção ficcional do Brasil contemporâneo.

Dessa forma, a esfera estética de um mundo tão hipermimético, com cenas de violência tão estarrecedoras, significa decisão e compromisso de se apropriar do real, reconfigurando-o, porém, como uma existência descentrada, com suas formas culturais próprias $^{6}$ e desabrigada pelo poder público, que torna seus olhos

alimenta a violência cria indivíduos cruéis que não têm a simpatia dos leitores como o malandro. Não haverá mais convívio harmônico entre marginal e sociedade.

${ }_{5}$ Antonio Candido (1989) justifica essa tendência realista-naturalista por uma demora cultural. O Brasil ainda tem problemas de ajustamento e de luta com seu meio, bem como problemas ligados à diversificação racial, tendo, assim, prolongado suas preocupações naturalistas.

${ }^{6}$ Funk, rap, hip-hop, samba etc. 
para os interesses das classes dominantes. No plano estritamente infantil, trata-se de captar os deslocamentos dos pequenos seres, duplamente penalizados pelo abandono da família e do Estado; muitos deles, nas obras analisadas, vão para o mundo do crime, motivados pelos pais ou como forma de escape de pais violentos. Um retorno do trágico se traduz então em forma de errância, tendo em vista que as crianças desse mundo periférico se veem obrigadas a seguir um caminho oblíquo bastante distante do ideal de existência de uma infância normal.

\section{Regime imaginário da infância}

O estudo de Monique Boucher (2011), dedicado à temática da infância associada à da errância, nos romances contemporâneos do Québec, mostra como se compõe o feixe de relações simbólicas correlacionadas. Esse feixe é investido de ideias concernentes ao estado de pureza, não corrompido, que caracteriza a infância, já debatido por muitos séculos. No Québec, muitas crianças estão presentes na literatura, e a infância constitui o período de vida ideal, mesmo se existem momentos de tormenta e de angústia. Dois blocos de pensamentos se encontram para evidenciar as razões dessa presença constante: 1) apresentam-se os atributos da infância, de forma a supervalorizá-los; 2) denuncia-se o universo dos adultos, figuras antitéticas representando o poder e responsáveis pelo esvanecimento dos sonhos de felicidade. Tem-se assim, como no caso do romancista Réjean Ducharme (apud Boucher, 2011), uma criança rebelde, vítima dos princípios morais e das convenções sociais; sua revolta acentua o hiato entre o mundo da infância, do sonho e da magia, e o dos princípios rígidos que regem a ordem social dos adultos dominadores. Se os adultos negam aos pequenos seres o reconhecimento social, estes aproveitam seus tempos de liberdade para inventar jogos lúdicos e criativos que transcendem o mundo opressor dos maiores.

Boucher mostra igualmente que o mundo das crianças se inscreve no regime noturno do imaginário que, segundo Durand (apud Boucher, 2011), é aquele das figuras simbólicas da descida, da retração, do útero, da mãe, da intimidade, em contraste com as figuras do regime diurno, que são as da subida: ascensão, poder, iluminação, razão. Observemos 
que as imagens ligadas ao regime noturno possuem uma força simbólica de cerca que prepara e delimita um espaço próprio, apto a deixar emergir as expressões espontâneas do mundo infantil. Um contraponto ao tema da infância ideal aparece como a quebra do pacto de clima edênico, quando a criança deixa sua cerca simbólica para se lançar na vida e trilhar um caminho de errância. $\mathrm{O}$ abandono de um mundo circular, maternal e cíclico ressalta um imaginário de ruptura que é característico do regime diurno, vertical, impulsivo, fálico.

A errância tem várias faces, através de narrativas diversas na história da humanidade, como o assinala Olivieri-Godet (2010): algumas positivas, como aventuras voluntariamente assumidas, levando a uma desterritorialização de pertencimentos arraigados; outras negativas, como desenraizamento involuntário, acentuando a violência das travessias de territórios desconhecidos. De qualquer forma, o rico simbolismo da errância, com suas múltiplas figurações moduladas, conduz ao estabelecimento de uma temática em contraponto àquela do culto da infância idealizada. Tal temática acarreta o pensamento da expulsão, pronto a desconstruir a glorificação dos atributos de uma infância feliz, permitindo a emergência de figuras de mobilidade marginal, como os vagabundos, malandros e quadrilheiros. Evidentemente, contemplar figuras infantis marginais significa ressaltar o fato de que uma determinada sociedade, como centro de agrupamento integrador de seus cidadãos, sofre de anomalias estruturais que se evidenciam incapazes de garantir as condições necessárias para uma existência infantil adequada.

\section{Capitães da areia, a infância abandonada na década de 1930}

Na produção amadiana, a cidade da Bahia, como Salvador é conhecida, é também personagem e autor, como o diz Jacques Salah (2008, p. 38). O papel que ela desempenha na formação históricocultural do país, como espaço e território é fundamental, principalmente que ela funciona como "loci de construção discursiva", proporcionando a emergência de imagens que favorecem a valorização, com uma consequente autoestima, de mundos de vida de uma determinada coletividade.

É comum aparecer, nos romances de Jorge Amado, a divisão em cidade alta e cidade baixa, em Salvador, evocando a clivagem 
econômica, social, cultural e racial, divisão esta que colabora com a visão de cidade misteriosa e labiríntica ligada por becos e ladeiras. Salah (2008, p. 38) assinala que, na realidade, há dois tipos de cidades baixas ${ }^{7}$ e dois tipos de cidades altas. ${ }^{8}$ Esse espaço urbano vivo possui, assim, uma grande variabilidade de relações, podendo ser visto como um palimpsesto, de difícil apreensão. Sua configuração, modelada pelas transformações do aburguesamento progressivo da cidade alta, embelezada e ajardinada, vai contrastando com os velhos casarões que ainda abrigam hábitos coloniais vistos como ultrapassados.

Nesse contexto, Jorge Amado, membro do partido comunista, empreenderia uma crítica aos valores burgueses, criando uma ficção eivada de várias tensões entre comportamentos malandros, crenças afro-brasileiras seculares e manifestações culturais populares nascidas nas ruas e nos territórios de exclusão "que deviam ser resgatadas para a dizibilidade do país e da região (Nordeste)" (Albuquerque Jr., 1999, p. 216). Ele mostrou a formação dos grupos de capitães da areia, crianças abandonadas que ainda amavam sua cidade, transformando-a em parceira de luta, e que ainda possuíam um senso de humanidade infantil, com muitos códigos de solidariedade para se protegerem. ${ }^{9}$

O primeiro capítulo de Capitães da areia, intitula-se "Cartas à redação". O autor utiliza, dessa forma, um dispositivo semiótico de pluralizar os focos narrativos, tornando os tipos de saber e de visão

\footnotetext{
7 "Existe uma cidade baixa dos bancos e do comércio atacadista - que tende aliás, a desaparecer, com o surgimento de bairros recentemente criados - e, de outro lado, a cidade baixa dos velhos prédios sórdidos que abrem suas portas à prostituição desde o anoitecer. Não é raro que algumas personagens dos romances amadianos possuam casas comerciais na cidade baixa enquanto moram nos bairros ricos da cidade alta" (Salah, 2008, p. 40).

8 "Desde o início da colonização, os nobres e ricos burgueses se instalaram na parte da cidade alta que assistiria ao nascimento dos bairros do Pelourinho, da Sé, - ou Centro -, do Paço. Os prédios ricos que eles edificaram - os sobradões - foram pouco a pouco abandonados para as populações miseráveis e para a prostituição [...] De qualquer forma, a antiga oposição permaneceu, e nos referimos sempre aos bairros ricos quando falamos da cidade alta, mesmo se isso diz respeito apenas a bairros como Campo Grande, Vitória ou Graça" (Salah, 2008, p. 40).

${ }^{9}$ Pode-se perceber uma semelhança temática, a irrupção alegórica do gamin de Paris, Gavroche, o menino pobre das ruas, personagem de Les misérables, de Victor Hugo (1862), visto como a encarnação alegórica do povo expulso da nova cidade virtuosa, esplendorosa e opulenta (Pesavento, 2002, p. 78). Como o maltrapilho Gavroche, os capitães da areia, "vestidos de molambos", contrastam com a "linda criança", Raul, neto de um comendador, "um dos ginasianos mais aplicados do Colégio Antonio Vieira" (Amado, 1998, p. 6). Os malvados capitães são também andarilhos, como o gamin de Hugo, pois "não têm moradia certa [...], ainda não foi localizado o local onde escondem o produto de seus assaltos, [...] o cais é o seu quartel general" (Amado, 1998, p. 3). E é o cais que lhes permite ganhar a alcunha de capitães da areia.
} 
variados. Cartas dirigidas ao jornal $A$ Tarde $^{10}$ dão conta de um dos delitos das "crianças ladronas [...] que infestam nossa urbe" (Amado, 1998 , p. 3). Imediatamente, o espaço urbano é a esfera de configurações de um problema social no qual se revelam novas formas de enfrentamento das novas classes sociais que estão se formando nesse início de século. A urbe em questão é a parte mais organizada da cidade baixa, a rua Portugal, e a parte mais bela da cidade alta que se notabiliza pela elegância da arquitetura, o Corredor da Vitória, cuja estética das edificações e da paisagem se conjuga com o ethos pacífico e honesto de seu proprietário, um comendador, pai de família exemplar. O recurso ao uso de outros registros discursivos, cartas e artigos do jornal, que não são compartilhados pelo narrador, possui uma força argumentativa na escolha dos atributos selecionados para caracterizar o mundo do trabalho dos negociantes de "nossa urbe", que, desde já, passa a constituir um cronotopo ${ }^{11}$ de materialização de virtudes e vícios, agora imbricados em um jogo semiótico de inclusão e exclusão.

A virtude está, de todas as evidências, conectada à expansão dos negócios, no seio do desenvolvimento capitalista que permite o sonho da constituição de uma cidade ideal, de "belas vivendas", síntese das novas ideias de percepção espacial, uma "arquitetura colonial" com inovações baseadas nos princípios higienistas europeus, com as residências separadas com recuos laterais, jardins e sanitários próprios. ${ }^{12}$ As novas classes abastadas abandonavam o estilo colonial das estreitas e acidentadas ruas do Centro Histórico.

Como na mídia atual, o articulista da página de "Fatos policiais" põe em evidência seu dispositivo enunciativo para compor a autoridade da fonte emissora das notícias: nesse momento, estabelece-se o contraponto entre a criança do mundo da virtude, da inclusão social, que fala de sua bicicleta e de muitos brinquedos, e os pequenos "Gavroches" que menosprezam tais brinquedos, valorizando a liberdade das ruas e do cais, como verdadeiros seres da exclusão na cidade-vício. Essa reportagem sobre o enfrentamento de crianças distintas, no qual Pedro

\footnotetext{
${ }^{10}$ Que ainda é o maior jornal do Norte e do Nordeste.

${ }^{11}$ Cronotopo, conceito de Mikhail Bakthin, concebido como uma forma arquitetônica da narrativa que configura modos de vida em contextos particulares de temporalidades. É uma categoria em que tempo e espaço são construídos na composição da obra literária como texto de cultura (Machado, 2010).

${ }^{12}$ É a influência de Lucio Costa e Paulo Santos, líderes de um grupo de jovens arquitetos que, a partir de meados da década de 1930, implantou a arquitetura moderna, que mesclava referências dos conceitos de Le Corbusier com a tradição colonial brasileira.
} 
Bala fere o jardineiro da casa (cuja foto é, aliás, exibida no jornal com o comendador no momento em que era condecorado), abre uma discussão sobre a situação tenebrosa que engendra esse lado noir da cidade, envolvendo crianças abandonadas.

São vários os registros discursivos que emergem, nesse início da diegese, buscando explicar a situação delinquente em que os capitães se encontram, já formando o embrião de um lumpesinato urbano. Raul, o rico, admira o menino Pedro Bala, comparando-o a um aventureiro de cinema, e o articulista do jornal alerta para os perigos das novas estórias fílmicas que exploram façanhas perigosas para a educação de crianças. O Secretário do Chefe de Polícia envia uma carta ao jornal, publicada na primeira página, afirmando que a solução do problema deveria ser apresentada pelo dr. Juiz de Menores e não pela polícia. Esse juiz, por sua vez, responde que é a policia que deve capturar os menores delinquentes, e o juizado de menores é uma instância à qual compete "velar pelo seu destino posterior", isto é, encaminhá-los ao Reformatório. O problema é que o juiz se depara com a difícil situação da fuga das crianças que voltam das ruas, quando recapturados, "ainda mais perversos como se o exemplo que houvessem recebido fosse mau e daninho" (Amado, 1998, p. 8).

A partir dessa afirmação do juiz, seguem-se duas cartas bastante significativas e aptas a configurar a semiótica institucional referente a esse novo mundo de contrastes, entre um mundo galante e um meio de pobreza e abandono. Como legislar e encontrar as fronteiras simbólicas capazes de estabelecer territórios adequados de poder? Uma mãe costureira, signo da família, solicita ao repórter para ir verificar as condições de vida "no tal do reformatório para ver como são tratados os filhos dos pobres que têm a desgraça de cair nas mãos daqueles guardas sem alma" (Amado, 1998, p. 10). Em seguida, reage a voz representativa da igreja: o padre José Pedro ${ }^{13}$ concorda com os argumentos da mãe, acrescentando que as crianças no "aludido Reformatório são tratadas como feras" (Amado, 1998, p. 12). Como veículo religioso, ele leva consolo aos meninos, que, já revoltados pelos espancamentos e castigos desumanos, não possuem mais disposição para ouvir palavras apenas de alento. Por fim, escreve o Diretor do Reformatório Baiano de Menores Delinquentes e Abandonados, comentando sobre as duas

\footnotetext{
${ }^{13}$ É um padre negro, considerado medíocre pelo clero, pois tirava notas baixas no Seminário.
} 
cartas de acusação que leu: uma de uma "mulherzinha do povo", que não merece resposta, e a outra de um sacerdote que ele considerava como um "padre do demônio", que penetrava no "estabelecimento de educação" (Amado, 1998, p. 13) para provocar a revolta dos menores. Para este, as portas estariam doravante fechadas, mas um repórter deveria ir lá para verificar a maneira como as crianças se regeneravam nesse reformatório. A partir desse pedido do diretor, são mostrados títulos de artigos que se seguiram: "Um estabelecimento modelar onde reinam a paz e o trabalho", "Um diretor que é um amigo", "Ótima comida", "Acusações improcedentes" (Amado, 1998, p. 15) etc.

Esse início do romance, entrecruzando vozes institucionais, ${ }^{14}$ mostra como a cidade é o palco da construção da ordem moderna e que essa ordem é regulada pela significância política e ideológica articulada por vários tipos de processos discursivos. E qual o melhor veículo de comunicação para a produção e a circulação de discursos que não a mídia que, nesses anos 1930, era basicamente o jornal impresso? As identidades sociais dos sujeitos que enunciam põem em cena um ritual discursivo que contribui para a constituição representativa de várias dimensões da estrutura social que permitem a delinquência das crianças.

Primeiramente, os artigos, que aparecem na parte policial do jornal, enfatizam o lado criminoso dos meninos. Segundo, os artigos contribuem para reproduzir as relações sociais do novo espaço urbano que se configura em Salvador. A cidade se capitaliza e as classes sociais se enfrentam em uma esfera de concentração de riqueza e renda. A pobreza, que se constitui de pessoas inseridas na vida social precariamente, não consegue se inserir no mercado do trabalho e, consequentemente, não apresenta atributos positivos para configurar uma cidade ideal, com as características de espaço edênico. Pelo contrário, apreende mais facilmente os qualitativos negativos da cidade-vício, cuja natureza se apresenta com vestígios representativos de espaço infernal.

Após essa apresentação dialógica, Capitães da areia desenvolve sua rede espacial em torno da construção de uma comunidade de meninos no trapiche abandonado. Uma tensão orgânica entre a ideia de conjunto no bando de garotos de rua, em uma espécie de errância organizada, e o nível ontológico de cada um animam as peripécias da narrativa na qual se podem vislumbrar os objetos individuais de desejo.

\footnotetext{
${ }^{14}$ Incorporações da voz da igreja, da família (pobre), de um diretor, de um comendador, do delegado de polícia, do juiz de menores, dos jornalistas.
} 
Vejamos algumas características de alguns dos capitães da areia, que são os pilares dessa trama narrativa. Pedro Bala é considerado o chefe, vive nas ruas há dez anos, desde que seu pai, um sindicalista, recebeu um balaço da repressão, e é o grande conhecedor de todas as ruas e becos da cidade. Sua tendência para a liderança emana do fato de que se volta para as vozes de seu pai desaparecido e de João de Adão, um negro sindicalista, um dos poucos adultos que respeitam e se preocupam com a vida do bando. ${ }^{15}$ João José, o Professor, desde o dia em que furtara um livro numa casa da Barra, passara a ser perito em furtos de livros, que ia empilhando num canto do trapiche. Era ele quem lia as notícias do jornal para todos. Sem-Pernas era um deficiente físico, com uma perna coxa, utilizado pelo grupo para causar piedade nas casas mais abastadas onde era acolhido para observar os costumes das famílias e, mais tarde, trazer as outras crianças para furtar. Gato, "vaidoso, elegante e com pinta de malandro" (Amado, 1998, p. 35), vivia entre as prostitutas, atraindo uma delas para si, a Dalva. Pirulito, "de boca rasgada e pouco risonha" (Amado, 1998, p. 28), furtava objetos sagrados, pois tinha fé e era o único que realmente prestava atenção aos dizeres religiosos do Padre José Pedro; ouvia a voz de Cristo. Volta-Seca sonhava ser cangaceiro, dizendo-se afilhado de Lampião, de quem o Professor sempre lia notícias nos jornais; em sua raiva contra as autoridades, ouvia a voz do cangaço. Boa Vida era um dos moleques espertos do trapiche, que também participava dos roubos, voltando sua atenção para todos os malandros, conquistadores, valentões e cantadores de $\mathrm{ABC}$ da cidade.

Na comunidade do trapiche, onde vivem pessoas tão diferenciadas, ${ }^{16}$ a tensão orgânica entre o conjunto e o individual impulsiona a trama em uma cidade labiríntica, com sua multiplicidade de sistemas partilhados que aceita a diversidade de sentimentos. Cada cidadão prova uma experiência que o preenche em graus variados. Aí existem as dicotomias rico/pobre, espaço aberto/espaço institucional, que direcionam, de alguma forma, a errância dos garotos. Há o tempo do movimento, dos deslocamentos marginais pelos becos labirínticos da cidade, e há o tempo do sono, quando o bando se recolhe em seu espaço exíguo. Aqueles que "atemorizam" a cidade, em um regime representativo de

\footnotetext{
${ }^{15}$ Os outros são o Padre José Pedro e a mãe de santo Don'Aninha.

16 Jorge Amado prima pela arte de mostrar a construção de comunidades de excluídos, com idiossincrasias múltiplas, que funcionam bem com seus próprios códigos. Vide Tocaia Grande (1984).
} 
tipo diurno, que os impele para as aventuras marginais das existências em errância, são vencidos pelo cansaço, nas noites frias do cais da Bahia. O trapiche é então descrito como esconderijo de pequenos delinquentes, mas igualmente como o território do regime noturno da imaginação, em que o espírito da desagregação da ordem, com a confusão da lembrança das atividades marginais, dá lugar ao desejo de reclusão e de repouso, com sentimentos de fraqueza, naqueles pequenos seres que passam a vida a espalhar o medo.

Duas faces da cidade se entrelaçam na narrativa, indicando a parte bela e misteriosa que convida à liberdade, o regime diurno e o regime noturno, com seus espaços confinados, dos quais os excluídos vão se apropriando para construir as chamadas comunidades periféricas nas quais se abrigam os desassistidos pelas políticas sociais.

Em uma natureza infantil, a tensão entre o regime diurno e noturno adquire contornos dramáticos, no sentido de que é uma idade que necessita de uma cerca simbólica consistente com amor e respeito, assim como de uma educação e de uma ética apropriadas para a vida social. Essa tensão dramática aparece, com bastante acuidade, no momento em que Sem-Pernas é acolhido pela família abastada, que perdera um filho, e entra em conflito, ao encontrar um ambiente confortável para sua vida de criança deficiente. Ele tem, entretanto, de se desterritorializar imediatamente para respeitar o código de solidariedade dos capitães, passando ao grupo os locais dos objetos de valor que poderão ser subtraídos. Nesse momento, a cidade que se queria bela já registrava uma série de habitações precárias que não apenas eram contrárias aos princípios da estética, como eram abrigo de inúmeros foras da lei, e Sem-Pernas, ao voltar ao trapiche, se mostra rude e agressivo no reencontro com seu território de pobreza.

No lado da "cidade alta rica", desenvolviam-se os palacetes belos e higiênicos, de acordo com os novos tempos inspirados na ideia republicana do progresso. Mas a cidade colonial que se ensaiava moderna com o embelezamento do espaço continha ainda sintomas de enfermidades endêmicas, capazes de dizimar grande parte da sociedade, ${ }^{17}$ como será visto com a chegada da varíola, iniciada no capítulo "Alastrim".

\footnotetext{
${ }^{17}$ Salvador continua com grandes epidemias de dengue e meningite, que têm dizimado muitas pessoas. A vacina contra meningite custa $\mathrm{R} \$ 100,00$, e o governo, quando fornece, reserva-a apenas para crianças de menos de 4 anos.
} 
Na cidade do progresso e das virtudes, a vacina representa a ciência posta a serviço das classes abastadas, que dispõem de serviço médico adequado. Na cidade dos pobres, ocorre a derrota do orixá Omolu, que só conhece as florestas da África, longe da civilização, e, por um gesto de ignorância em relação às novas possibilidades médicas e sanitárias, libera a doença para atacar os ricos. Evidentemente, essa atitude errônea do Orixá não representa apenas uma irrupção do fantástico na narrativa, mas indica a presença da herança popular de elementos africanos marginalizada do processo de modernização. "Os candomblés batiam dia e noite, em honra a Omolu, pra aplacar a fúria de Omolu", mas o único resultado que obtiveram foi o de reduzir o número de mortes, pois Omolu, enfraquecido diante da ciência, só pode "tirar a força da bexiga negra", transformá-la em alastrim, 'que é uma bexiga branca e tola, quase um sarampo" (Amado, 1998, p. 133).

Essa é a dinâmica narrativa da cidade dividida. É uma linha de história espacial que indica que os pobres que não tinham acesso às ferramentas médicas da cidade do progresso e eram obrigados, pelo governo, a ir morrer no lazareto, um espaço de saúde pública, desregulamentado, desprovido de ciência e de cientistas, uma espacialidade social, enfim, atravessada de barbárie e miséria.

Nos terreiros, "as macumbas pediam que ele (Omolu) levasse a bexiga da cidade, levasse para os ricos latifundiários do sertão" (Amado, 1998, p. 150), mas o orixá insistia em dizer que não era ele que estava matando os filhos negros e pobres, e sim o lazareto. $\mathrm{O}$ foco da denúncia amadiana exterioriza-se contra as políticas públicas responsáveis pelo aniquilamento dos mais pobres, pois os detentores dos cargos e setores responsáveis pelos problemas urbanos e ações diretas sobre a cidade negligenciam explicitamente essa camada social composta, em sua maioria, de negros. O saber ancestral, então, capitula diante do novo projeto urbano, alicerçado na ciência médica e sanitária, e "numa noite de mistério da Bahia, Omolu pulou na máquina da Leste Brasileira e foi para o sertão de Juazeiro. A bexiga foi com ele" (Amado, 1998, p. 150).

\section{Dora, mãe, irmã e noiva}

O capítulo "Filha de Bexiguento" mostra como a lavadeira Margarida contrai o alastrim e não consegue vencê-lo, vindo a falecer. Seus dois filhos, Dora, uma menina de 13 anos, e Zé Fuinha, de seis, 
ficaram órfãos no "morro", cujo "barracão" ("bem situado, bem no alto da ladeira"), onde moravam, foi logo desinfetado com álcool para ser alugado. Dora resolveu deixar para trás esse território onde cresceu, abandonando "as músicas dos violões e o samba", e os vizinhos que se reuniam para resolver sobre seu destino, para "queimar os pés no asfalto ardente" (Amado, 1998, p. 158), em busca de vida nova.

Dora atravessa a cidade, em direção do bairro nobre da Barra, onde chega diante de um palacete rodeado de grades. No jardim da casa, um adolescente brinca com a irmã e, ao vê-la, observa seus seios que despontam e imagina situações eróticas que viriam a acontecer, caso sua mãe a contratasse como faxineira. Mas esse cenário, de base colonial e escravagista, em que os patrões abusavam das criadas, logo se desfaz, pois a dona da casa não admite contratar alguém cuja mãe faleceu com bexiga, e o rapaz "cospe com nojo", pensando nos seios da menina "marcados de varíola" (Amado, 1998, p. 160).

Nessa deriva, sofrendo de cansaço e fome, Dora encontra o Professor e segue com ele até o trapiche. É a primeira menina a integrar o bando, e sua chegada não é harmoniosa, pois excita o desejo da maioria dos meninos, que pensam em estuprá-la, o que não acontece devido à proteção do Professor e, em seguida, de Pedro Bala. Dora torna-se uma capitã da areia, com uma navalha, associada à Rosa Palmeirão, efetuando furtos com o bando e aprendendo a liberdade das ruas: "Já não achava a cidade inimiga. Agora a amava também, aprendia a andar nos becos, nas ladeiras, a pongar nos bondes... Era ágil como o mais ágil" (Amado, 1998, p. 178). Ao mesmo tempo, a menina se torna o elemento afetuoso que trata das roupas e dos objetos do grupo, e passa a ser considerada como a irmã ou como uma jovem mãe.

A presença feminina de Dora, conotando o lado maternal, de madre protetora, que dera colo, carinho e atenção, já foi bastante analisada por vários estudiosos. Em tais condições adversas de uma urbanidade desigual, em uma situação de resgate da natureza humana no deletério, o elemento feminino é convocado a indicar como afrontar as dificuldades sociais em nome do lado comunitário, de solidariedade entre os elementos de uma comunidade tão diferenciada que se unia contra a instauração de uma urbanidade injusta e destruidora. ${ }^{18}$

${ }^{18}$ Como o papel de Lívia em Mar morto. 
Justamente, atuando com solidariedade junto com os capitães, Dora é capturada, ao mesmo tempo em que Pedro Bala. Este sofre castigos pesados no Reformatório, sendo mesmo confinado na Solitária, confirmando a ideia inicial, exposta na carta ao jornal de uma mãe, de que tal estabelecimento tratava os meninos como feras. Quanto à menina, ela perde a alegria de viver, em um mês de orfanato, pois já havia se habituado à vida aventurosa de liberdade junto aos capitães. Começa a ter muita febre e a ficar debilitava, odiando o silêncio da enfermaria, onde não conseguia perceber nem um raio de sol.

Os capitães conseguem liberá-la e a levam de volta para o trapiche, onde cuidam de sua irmã, mãe e noiva. Eles instauram seu território de humanidade, buscando a mãe de santo, com seu saber medicinal ancestral, para curar o único integrante feminino da comunidade. Dora e Pedro Bala se tornam esposos. Quando ela falece, no dia seguinte, os meninos a levam para o mar, para que ela fosse integrar o reino de Iemanjá. O mar seria, nesse momento, o lugar privilegiado de rebeldia contra os rituais de funerais católicos, aceitos pela sociedade. Os meninos rejeitados, em sua errância marginal, mostram-se mais uma vez capazes de construir seus próprios elos de sociabilidade, buscando a reterritorialização da cultura ancestral, que é um dos meios que o romance encontrou para exprimir a responsabilidade do grupo em uma possível mudança social. Os meninos resistentes podem, assim, a qualquer momento, redinamizar e reatualizar, em um espaço urbano hostil, os personagens míticos de uma cultura rechaçada.

De uma forma geral, o desenlace individual se apresenta assim: Dora virou uma estrela no céu; Pedro Bala, um sindicalista; João Grande embarcou num cargueiro da Llóide; Boa-Vida permaneceu mais um malandro da cidade; Sem-Pernas se jogou do Lacerda, fugindo da polícia; Professor foi para o Rio ser artista plástico; Pirulito seguiu os passos do padre Pedro José; Volta-Seca foi para o cangaço; Gato foi para Ilhéus com Dalva ganhar dinheiro trapaceando os coronéis do cacau; e Barandão se integra igualmente nas lutas obreiras.

Observa-se então que, com o recurso retórico da sinédoque/metonímia, Amado desdobra o caráter e os desejos de cada menino, como se eles pudessem indicar a representação de formações discursivas com suas investidas ideológicas. Nesse caminho retórico, a cidade, com seu projeto urbano de modernização, torna-se mais uma sinédoque apta a mostrar os desafios de se configurar a espacialidade 
do social, negligenciando suas classes mais desprovidas de recursos. A cidade da Bahia, antropomorfizada por vários poetas como a morena dengosa das curvas belas, passa por um processo de desestetização, parecendo ser representada pela menina Dora, que se associa ao bando de meninos, mas sucumbe diante de maus tratos e falta de cuidados com a sua sensibilidade. A cidade, como uma amiga, mãe e noiva, gera uma constelação de sentimentos e desejos imbricados, exigindo negociações complexas para que sejam fornecidas a todos condições mínimas de vida. Essa é uma visão de mundo afixada no romance. Mas, no processo contínuo da errância, alguns dos capitães encontram um caminho de esperança para a construção de uma vida mais honesta, como o Professor, Pedro Bala e Pirulito. Outros, entretanto, vão engrossar as fileiras dos malandros da Bahia, como o Boa Vida e o Gato, e do banditismo social do sertão, como Volta-Seca.

Não se pode negar que a literatura aqui, de todas as evidências, acendeu o sinal de alerta para o que o futuro faria com as crianças das classes excluídas. Tais crianças, ainda contempladas no seio da dialética da malandragem, retiradas de sua cerca edênica muito cedo, fariam para si uma identidade, adicionando fragmentos dos patrimônios simbólicos examinados e usurpados. Chegariam a sua liberdade, escolhendo suas crenças, fidelidades e obrigações; munir-se-iam de uma memória coletiva específica, conservando a dos ancestrais ou rompendo com ela, mas sempre contraindo novas alianças, novas amizades e alteridades (cangaço, malandragem, vida religiosa, vida sindical, artes plásticas). Representar-se-iam novas continuidades a partir de seus momentos de ruptura e de dissolução do bando; passariam a fundar uma história própria, reprogramando seus imaginários.

\section{A marginalidade infantil em Cidade de Deus}

Em Cidade de Deus, as crianças passariam a programar seus imaginários, na dialética da marginalidade, já emergindo na cena social filiados a um grupo ou milícia delinquente, que vai evoluindo até pertencer a uma quadrilha do tráfico de drogas. Em geral, não existem crianças totalmente deslocadas aptas a praticar desenraizamentos, e sim mais personagens suscetíveis de proclamar a continuidade do tráfico, de tomar uma posição na hierarquia estratificada das facções existentes em 
suas comunidades. Mas, antes de observarmos o engajamento das crianças nessa vida marginal, vejamos a estrutura de Cidade de Deus.

O narrador inicia a primeira parte do romance, correspondente aos anos 1960, na terceira pessoa, um ponto de vista mais distanciado dos personagens. É com o estilo bucólico que ele descreve o espaço onde a pujança e a pureza da natureza, reminiscências da Mata Atlântica, mostram lugares originais da terra virgem, que foram sendo ocupados pelos seus primeiros ocupantes, os portugueses e os negros africanos. Em seguida, o narrador continua mostrando como a natureza muda para dar lugar ao povoamento: "Cidade de Deus escasseou a flora e a fauna, remapeou Portugal Pequeno e renomeou Charco: Lá em cima, Lá na Frente, etc." (Lins, 2002, p. 16). A favela foi transformando-se em neofavela, para onde migraram vítimas de enchentes de outros locais periféricos, levando todos seus velhos "cacarecos" e ainda mais "pobreza para querer enriquecer"; mas chegaram alegres cantando "Cidade maravilhosa". A enumeração de objetos, sentimentos, corpos feridos e ensanguentados constitui igualmente aquela esteira de qualidades sensíveis que forma a movimentação plástica da fundação da favela. Fisicalidade sonora e visual, uma morfologia icônica que diz respeito à composição do território que se estende durante uma semana, com "olhos e peito para encarar a vida" (Lins, 2002, p. 17).

A multidão em marcha ilustra a reterritorialização da neofavela, assim como a existência de complexas teias de relações físicas, entre objetos deteriorados (resquícios de enchente, lixos, latas, panos de chão), armas, animais domésticos e animais de rituais de macumbas, assim como teias de relações sociais entre pessoas religiosas, raivosas, vingativas, esperançosas, trabalhadoras etc. As formas representativas desse hibridismo plástico, mesmo quando reproduzem a aparência das coisas visíveis, conduzem a percepção a um caráter simbólico e abstrato destinado a evocar conhecimentos culturais bastante específicos para o entendimento dessa união mágica de pessoas diferentes que chegam cantando, apesar do sofrimento.

Na primeira década descrita, é narrada a formação do Trio Ternura, três ladrões unidos que "fizeram história" na comunidade. Um deles, Marreco, era o irmão de Busca-Pé, o garoto fotógrafo que luta para escapar do mundo do crime. Esses ladrões saqueiam o caminhão do gás e convidam os vizinhos a se servir, o que ilustra uma movimentação rápida de pessoas correndo, inclusive os três, para escapar da polícia que chega 
em seu fusquinha de patrulha. Com efeito, a rede de signos que torna apreensível esse referente dinâmico da favela admite grande variedade de formas, apresentada numa configuração de descrição qualitativa.

Essa movimentação plástica continua, em outro nível, com uma descrição dos garotos que, com suas brigas e jogos, permite mostrar a formação dos elos subjetivos e sociais da nova comunidade que se constrói na neofavela: amizades, rixas e romances nessas pessoas reunidas pelo destino (Lins, 2002, p. 31). Nessa primeira parte, a focalização desliza para os personagens Barbantinho e Busca-Pé, cujos sonhos de ascensão social e mudança de vida são enfatizados. Busca-Pé torna-se um personagem relevante à medida que seu sonho de ser fotógrafo transforma-o em refletor da vida da sua comunidade, através do qual se pode criar um jogo de referentes e contrarreferentes para repensar os seres narrativos. Passando a ser um personagem que coloca seu próprio problema de personagem, Busca-Pé é eleito um operador de iconicidade, tão bem que age como narrador principal no filme homônimo, com o recurso da voz off em primeira pessoa. Ou seja, ele passa a ser, com sua câmera fotográfica, o narrador metafictício que põe a nu o mecanismo criador que dá origem aos seres ficcionais do texto fílmico.

Busca-Pé não se envolvia com os rapazes assaltantes, como o menino perverso Dadinho (que se transformará no poderoso Zé Pequeno). Ele integrava o grupo dos "cocotas", formados por adolescentes, em sua maioria brancos, influenciados pela cultura estado-unidense. Não eram quadrilheiros perigosos, mas se estruturavam em bandos, com um estilo de comportamento agressivo e violento. Como um estilo de quadrilha mais estilizada (Souza, 2009), os cocotas frequentavam os "bailes de corredor", de fanqueiros que dançam e lutam, ao mesmo tempo. E Busca-Pé transitava, em ambientes diversos, da cultura popular da favela à cultura letrada da escola que poucos cocotas frequentavam.

Santos Souza (2009), nesse âmbito, estabelece paralelos entre BuscaPé e o personagem Professor, de Capitães da areia, tendo em vista que os dois tinham dons artísticos e a capacidade de ler, constituindo um entrelugar entre o mundo em que viviam (o trapiche e a favela) e um outro mundo suscetível de lhes oferecer uma melhor qualidade de vida. É igualmente visível, para esse autor, a semelhança entre o personagem de Lins e ele próprio, que, como um passador cultural, transitou da favela à vida acadêmica, escapando da sorte bizarra de outros meninos com quem conviveu na infância. 
Nesse âmbito, vários feixes metafóricos de heroísmo são formados para caracterizar esses "novos" personagens do realismo brutal que vão compondo bandos, assim como os chefes são constituídos como os novos coronéis urbanos. Em Cidade de Deus, o garoto malvado Dadinho/Inho se torna o Zé Pequeno/Miúdo, e sua transformação em chefe depende de uma iniciação em seções de umbanda em que entra em contato com o Exu Tranca Rua do Cruzeiro das Almas, o qual se identifica : "Eu sou o Diabo, moleco! Se quiser, eu te tiro desse buraco, esse, boto suncê num lugar formosado, esse, mas se tu querer se foder comigo, vamos lá..." (Lins, 2002, p. 178). Desde então, o chefe de quadrilha passa a se chamar Zé Miúdo, mudando sua identidade para governar a boca de fumo dos Blocos Novos, e os outros bandidos começam a observá-lo com medo e admiração.

Em relação às crianças de Capitães da areia, as de Cidade de Deus vivem confinadas na nova fortaleza do tráfico de drogas, que é a neofavela, e a descrição qualitativa em torno delas possui algumas diferenças, como o fato já explicitado de perambularem livres, valorizando os códigos de solidariedade e bravura, conseguindo mesmo burlar as normas rígidas e discriminatórias das elites baianas (Pires, 2009, p. 41). Enquanto alguns capitães da areia encontram uma saída política para a vida marginal, a exemplo de Pedro Bala, que se torna sindicalista, os meninos de Lins afrontam a sociedade repressora com armas, violentando e matando.

Cidade de Deus mostra como se configura a infância em um território formado por colagens de existências, no seio desse tecido mítico da bravura dos quadrilheiros. De início, as crianças ainda se apresentam em seu aspecto tradicionalmente lúdico, brincando no rio, "nadando contra e a favor", e deleitando-se no novo habitat, como se tivessem se mudado para uma "grande fazenda" (Lins, 2002, p. 17). É a configuração de uma infância rural, de regime imaginário noturno, cuja qualidade imagética aciona um conjunto sinestésico com estímulos táteis, gustativos e visuais, quando compravam leite fresco, arrancavam hortaliças na horta, colhiam frutas no campo e andavam a cavalo pelos morrinhos da Estrada do Gabinal.

Mas, assim como o rio, "alegria da molecada", vai se tornar, com o desenvolvimento do tráfico, uma morada de cadáveres, as crianças também sofrem, ainda com idade muito jovem, transformações, em suas naturezas infantis, que as levam ao mundo do crime. É bastante 
significativo quando o narrador da primeira parte mostra como os tons vermelhos do barro batido "viam novos pés no corre-corre da vida", e como o barro tirado do Monte Vermelho ia servindo para aterrar "parte do charco e para o emboço das primeiras moradias" (Lins, 2002, p. 19). Toda essa tintura vermelha da terra, como parte da base infantil da nova comunidade, vai se misturar com o sangue que passará a tingir o rio de vermelho, com os cadáveres da guerra que acontecerá mais tarde. Nesse caso, o vermelho que une o barro e o sangue serve de signoveículo entre uma curta infância interrompida e uma idade adulta inscrita nas classes perigosas, dedicadas à criminalidade com o tráfico.

Existem os meninos "anjos", famintos, assim chamados porque nasceram na Cidade de Deus e por não terem armas verdadeiras para realizar os assaltos, de forma que só assaltavam para comer. Um exemplo é o menino Lampião, que, quando volta para casa trazendo para o padrasto apenas uma coxa de galinha, fruto de assalto, é bastante surrado, mas vai dormir "sem derramar uma gota de lágrima, porque todo mundo sabe e nunca é demais repetir que homem que é homem não chora" (Lins, 2002, p. 245). Os anjos sonham se tornar bandidos, como os da quadrilha de Miúdo, para enriquecerem.

As crianças de Cidade de Deus encontram-se, assim, confinadas nas relações de força instauradas na fortaleza do tráfico, em que perdem os sentimentos de solidariedade e de humanidade que ainda existem nos capitães da areia, apesar do abandono em que estes se encontram e da brutalidade com que são tratados pelas instituições sociais destinadas a recuperá-los socialmente. Mas já é sabido que, exercendo o seu poder em determinada favela, o crime organizado controla totalmente o ambiente, instaurando um poder paralelo. Prestam variados auxílios, atuando na comunidade como solucionadores de problemas e conflitos, e exercendo funções que, normalmente, seriam do Estado. É uma força de monopólio, controlada por uma lei do mais forte, e aquele que se torna chefe pode ali exercer suas atividades e explorar um comércio, suas "bocas", da forma que melhor lhe convier, como um coronel urbano.

A ilustração significativa sobre a forma "educativa" que esse poder paralelo exerce sobre a infância encontra-se no momento em que Miúdo/Zé Pequeno pune as crianças que ousaram assaltar os próprios moradores da favela, ordenando um dos meninos a manipular uma arma para abater outro menino do grupo. Esse tipo de "didática" do crime mostra bem o confinamento das crianças na fortaleza dominada 
pelo traficante. Cenas de crueldade e de arruinamento dessa fase da vida, considerada como feliz, são hiperbolizadas, inserindo a narrativa na trilha do realismo brutal e hipermimético. É a questão da existência determinada pela brutalidade que se sobrepõe aos ideais de justiça social. Todos os pensamentos ligados às utopias de revolução popular se desvanecem, buscando interrogações sobre os destinos dessas crianças que são treinadas para serem "classes perigosas". Nesse instante, o traficante permite não apenas a emergência de uma compreensão oculta e negligenciada da história, por vários anos, mas também uma angústia diante de uma fatalidade cega e imprevisível que autoriza a prisão de uma geração de crianças num universo fechado, sem possibilidades de encontrar as saídas para um mundo mais humano. No filme Cidade de Deus, as imagens em que Pequeno treina os meninos para atirarem nos companheiros acentuam as qualidades geradas a partir da exibição de força e poder.

No fim das narrativas literária e fílmica, aquelas crianças treinadas pelo traficante para matar chegam para eliminá-lo justamente no momento em que, extorquido pela polícia e obrigado a entregar seu último centavo para não ser preso, Miúdo/Pequeno perde o poder. Vulnerável, então, diante de meninos armados, sucumbe para a nova força que está a emergir, que é a do Comando Vermelho. Nesse caso, as crianças, diferentemente dos capitães da areia, que ainda se encontram em um universo aberto das ruas, suscetível de indicar várias saídas, se veem em face de uma única via, que é aquela que a sua nova vítima (Miúdo/Pequeno) acabava de deixar, a via da formação do poder paralelo do tráfico de drogas. É a formação mais perfeita da marginalidade infantil, com a perda dos atributos de pureza e inocência, reciclando uma velha temática fictícia: as criaturas esmagam seu criador.

Essas crianças da marginalidade já perderam, desde o nascimento, sua candura, sua pureza simbólica. De todas as maneiras, suas relações com o mundo procedem da territorialidade do comando do tráfico. Elas se alienam, se enraízam, se comprometem, como se seguissem um destino natural, o que causa o desconcerto da dialética da marginalidade para o leitor. É o tempo do desencanto, seguido de temor, que não instaura nenhum signo de conforto para se pensar a identidade nacional. Pelo contrário, tal dialética estabelece um estranho vácuo na percepção de um ciclo cada vez mais presente na sociedade brasileira: exclusão/violência/extermínio, que toma a estatura de um 
comportamento frequente: "primeiro, a sociedade exclui, depois, recebe de volta os efeitos dessa exclusão sob a forma de violência; para então exterminar os que agora figuram como ameaça" (Cerqueira, 2007, p. 90).

\section{Conclusão}

Por se tratar de criaturas tão infantes, pode-se perceber a complexidade de uma realidade que coloca logo de partida o problema das desigualdades em um país que ainda não conseguiu resolver seus problemas político-sociais. Em termos simbólicos, o universo da infância, vitimado na precariedade dessa realidade social, se apresenta prejudicado na perda de suas imagens de pureza e inocência, que necessitam de quadros míticos de imagens - quarto, casa, escola, colo parental etc. - de intimidade suscetíveis a formar muralhas de proteção contra a crueldade do mundo exterior. Nesses cenários íntimos, do regime noturno, crianças vivem seus períodos iniciais, descobrindo o mundo através de referências lúdicas capazes de conduzir uma passagem adequada à vida adolescente e, finalmente, adulta.

Infância e errância, com entrada precoce no regime diurno, traçam uma espécie de percurso em que os pequenos seres ora se dispersam pelas ruas de suas cidades, quando abandonados pelos pais, ora são orientados para o crime organizado, até mesmo como uma forma de auxiliar no orçamento da família. Assim, longe da glorificação dos atributos da infância, a errância se desdobra como um processo negativo, mostrando as consequências sociais de uma dita expulsão edênica, representada pela negligência parental e pela falta de responsabilidade do Estado.

O que a comparação entre a obra de Amado, de 1937, e a de Paulo Lins, de 1999, nos informa? Na primeira, os pequenos delinquentes, munidos de sentimentos de solidariedade entre eles, e de amor por sua cidade, criam seus próprios códigos de vivência, que determinam suas relações com o mundo. Inseridos na dialética da malandragem, mantêm certos equilíbrios sígnicos entre sociedade e tradições ancestrais, provocando mais compaixão nos leitores do que o temor de desestabilizarem o cenário social. A simpatia pela rebeldia dos malandros emana do fato de que eles conseguem ser livres pelas ruas e, ao mesmo tempo, transitam nas diferentes esferas sociais, servindo de signo de problematização da existência do mundo institucional. 
Em Capitães da areia, existe um cruzamento reflexivo sobre o funcionamento da polícia, dos reformatórios, da religião, da família, na formação dos meninos abandonados. Já em Cidade de Deus, a marginalidade torna-se signo de violência perigosa, a qual causa danos fatais à sociedade e não desperta muita simpatia nas elites em que se situa a maioria dos leitores. A dialética que se opõe aqui é relativa ao fato de que os chefes marginais do século XXI, funcionando como espécie de coronel urbano, "governam" sua comunidade, provendo-lhe todas as necessidades, mas exigindo "obediência" às regras de funcionamento comunitário, orientadas pelo tráfico de drogas. As crianças, em geral, longe de poderem errar pelas ruas, criando seus próprios códigos e forjando suas identidades a partir de talentos pessoais, vão, desde cedo, integrar as quadrilhas do tráfico.

Nesse confronto da natureza infantil com um social politicamente desumanizado, habilmente conduzido pelos narradores do realismo feroz, com frequência, a complexidade da realidade retratada exige deixar transparecer as coesões significantes entre a visão endógena da miséria social e mental, e as descrições relacionais entre as variadas linguagens populares que caracterizam as periferias. Nesse âmbito, essa ficção construída para refletir a realidade de uma infância sufocada pela vida criminosa é, acima de tudo, uma chave para a compreensão da presença constante de algo mais profundo, traduzido pelo aniquilamento de toda uma geração perdida no caminho da violência social. E é uma perdição para a qual Jorge Amado alertou na década de 1930, se o país continuasse a desenvolver planos urbanos sem incluir as classes menos favorecidas, compostas em sua maioria de mulatos e negros, descendentes de escravos.

\section{Referências}

ALBUQUERQUE JR., Durval Muniz (2009). A invenção do Nordeste e outras artes. 4. ed. Recife: FJN/Massangana; São Paulo: Cortez.

AMADO, Cecília; GONÇALVES, Guy (2011). Capitães da areia. Telecine; Imagem Filmes, 96 min.

AMADO, Jorge (1984). Tocaia Grande: a face obscura. Rio de Janeiro: Record.

AMADO, Jorge (1996). Mar morto. 71. ed. Rio de Janeiro: Record. 
AMADO, Jorge (1998). Capitães da areia. 95. ed. Rio de Janeiro: Record.

BISPO, Maria de Fátima S. (2009). Pereba. In: SOUZA, Licia Soares de (Org.). Dicionário de personagens afro-brasileiros. Salvador: Quarteto.

BOSI, Alfredo (2002). Os estudos literários na era dos extremos. In: BOSI, Alfredo. Literatura e resistência. São Paulo: Companhia das Letras.

BOUCHER, Monique (2011). L'enfance et l'errance pour un appel à l'autre: lecture mythanalytique du roman québécois (1960-1990). Québec: Nota Bene.

CANDIDO, Antonio (1989). A educação pela noite e outros ensaios. São Paulo: Ática.

CANDIDO, Antonio (1993). Dialética da malandragem. In: CANDIDO, Antonio. $O$ discurso e a cidade. São Paulo: Duas cidades.

CERQUEIRA, Patrícia (2007). Os assaltos literários de Paulo Lins. In: NOVAES, Cláudio; BOTELHO, Marcos. Seis passeios por Cidade de Deus. Feira de Santana: Ed. UEFS.

FERRÉZ (2003). Manual prático do ódio. Rio de Janeiro: Objetiva.

FONSECA, Rubem (1989). Feliz ano novo. São Paulo: Companhia das Letras.

HUGO, Victor (1862). Les misérables. Disponível em: <http://goo.gl/u2zQYg>. Acesso em: 10 mai. 2015.

JAGUARIBE, Beatriz. (2010). Ficções do real: notas sobre as estéticas do realismo e pedagogias do olhar na América Latina contemporânea. Ciberlegenda, v. 2, n. 23, p. 6-14.

LIMA JR. ,Wálter (1989). Capitães da areia. Rede Bandeirantes.

LINS, Paulo (2002). Cidade de Deus. 2. ed. São Paulo: Companhia das Letras.

MACHADO, Irene (2010). A questão espaço-temporal em Bakhtin: cronotopia e exotopia. In: PAULA, Luciene de; STAFUZZA, Grenissa (Orgs.). Círculo de Bakhtin: teoria inclassificável. Campinas: Mercado de Letras.

MEIRELLES, Fernando (2002). Cidade de Deus. O2 Filmes, 129 min.

OLIVIERI-GODET, Rita (2010). Errância/migrância/migração. In: BERND, Zilá (Org.). Dicionário das mobilidades culturais: percursos americanos. Porto Alegre: Literalis.

PESAVENTO, Sandra J. (2002). O imaginário da cidade: visões literárias do urbano. 2. ed. Porto Alegre: Ed. UFRGS. 
PIRES, Viviane (2009). Barandão. In: SOUZA, Licia Soares de (Org.). Dicionário de personagens afro-brasileiros. Salvador: Quarteto.

ROCHA, João César (2004). Dialética da marginalidade. Folha de S. Paulo, 29 fev. Disponível em: < http://www1.folha.uol.com.br/fsp/mais/fs2902200404.htm>. Acesso em: 20 mar. 2015.

SALAH, Jacques (2008). A Bahia de Jorge Amado. Salvador: Fundação Casa de Jorge Amado.

SOUZA, Adilson Santos (2009). Buscapé. In: SOUZA, Licia Soares de (Org.). Dicionário de personagens afro-brasileiros. Salvador: Quarteto.

SOUZA, Licia Soares de (2009). Literatura e cinema: traduções intersemióticas. Salvador: Ed. UNEB.

Recebido em setembro de 2014.

Aprovado em fevereiro de 2015.

\section{resumo/abstract}

\section{Infância e errância: imagens da criança abandonada na ficção brasileira}

Licia Soares de Souza

O presente texto apresenta o feixe semântico e mítico em torno da temática da infância, indicando os ideais de inocência e pureza que caracterizam o início de uma existência. Se tais ideais configuram o espaço edênico suscetível de determinar as relações positivas que seres infantes desenvolvem entre si e com o mundo adulto, em um regime noturno da imaginação, a escapada do espaço indica uma errância negativa, capaz de destruir seu estado de inocência. Essa errância é observada nas crianças delinquentes de Capitães da areia, de Jorge Amado, que, abandonadas nas ruas de Salvador, perdem seu mundo de pureza em busca de mecanismos de sobrevivência. Em seguida, procura-se averiguar a situação das crianças em Cidade de Deus, de Paulo Lins, cuja inocência é comprometida sob o jugo dos coronéis do tráfico de drogas, como Zé Miúdo/Pequeno. Finalmente, conclui-se que a obra de Amado indicou as anomalias de uma sociedade de exclusão que permitia o abandono de crianças nas ruas, como se estivesse prevendo que a situação pioraria se não houvesse políticas de inclusão com distribuição de renda, visando à qualidade de vida da população.

Palavras-chave: infância, exclusão, Jorge Amado, Paulo Lins. 


\section{Childhood and errancy: images of abandoned children in the Brazilian fiction}

Licia Soares de Souza

This text presents the semantic and mythic feature of childhood, indicating the ideas of innocence and purity that characterize the beginning of an existence. If these ideals configurate an edenic space that can determine the positive relationships that children establish with themselves and the adult world, in the nocturnal regime of imagination, the escape from this space indicates a negative deviation, capable of destroying a state of innocence. We observe this deviation in the delinquent children in Captains of the sand, by Jorge Amado, which, abandoned in the streets of Salvador, lose their world of purity looking for mechanisms of survival. Then, we investigate the children in City of God, by Paulo Lins, whose innocence is undermined by the power of drug dealers such as Zé Miúdo/Pequeno. Finally, we conclude that Amado's work indicates the anomalies of a society of exclusion that allows children to be abandoned in the streets, as if he was predicting that this situation would get worse if the country did not apply policies of inclusion with revenue sharing, aiming at the quality of life of the population.

Keywords: childhood, exclusion, Jorge Amado, Paulo Lins. 